\title{
Fast Determination of Diesel Fuel Oxidation Stability by ${ }^{1}$ H NMR Spectroscopy
}

\author{
Jelena P. Vuković, ${ }^{1, *}$ Vlasta Srića ${ }^{1}$ and Predrag Novak ${ }^{2}$ \\ ${ }^{1}$ NA-Industrija nafte d.d., Refining \& marketing business division, Product development department, \\ Lovinčićeva bb, 10002 Zagreb, Croatia \\ ${ }^{2}$ University of Zagreb, Faculty of Natural Sciences, Department of Chemistry, Horvatovac 102a, HR-10000, Zagreb, Croatia \\ *Corresponding author: E-mail: jelena.parlov-vukovic@ina.hr
}

Received: 20-06-2014

\begin{abstract}
${ }^{1} \mathrm{H}$ NMR spectroscopy and multiple linear regression analysis were used to determine diesel fuel oxidation stability. Oxidation stability is one of the most important properties which affect diesel fuel characteristics and quality. It has been demonstrated that integrated peak intensities of certain functional groups in ${ }^{1} \mathrm{H}$ NMR spectra correlated well with the oxidation stability. This approach is fast, nondestructive and requires small amounts of samples. It has a potential to be used as an alternative to existing standard methods.
\end{abstract}

Keywords: Diesel fuel, oxidation stability, NMR spectroscopy, statistical analysis

\section{Introduction}

A common characteristic of diesel fuel is its very complex composition. Diesel fuel consists of hundreds of individual components belonging to aromatic, paraffinic, olefinic and polar hydrocarbon classes. Diesel fuel can be produced in a refinery from several middle distillates hydrocarbon fractions with boiling range from $180{ }^{\circ} \mathrm{C}$ to $350^{\circ} \mathrm{C}$. The minimum requirements for diesel fuel quality are defined in the standard, EN 590. ${ }^{1}$ All of diesel fuel properties are dependent primarily of the fuel composition. Oxidation stability (OS) is one of the most important properties which influences diesel fuel quality and significantly affects application characteristics of diesel fuels. Oxidation degradation is one of the most significant limiting factors for diesel fuel stability which affects the amount of insoluble sediments formed during oxidation. ${ }^{2,3}$ It is well known that the formation of sediments during oxidation is a complex process in which many compounds of stocks are involved, but the chemical nature of fuel sediments and exact mechanism of the sediment formation are still not fully explained and understood. ${ }^{4-6}$ It is generally accepted that oxidation reactions follow the free-radical mechanism. ${ }^{2,7}$ It has been reported in the recent literature by many authors that deposit formation during oxidation of diesel fuel is related to the presence of olefins, polycyclic aromatic hydrocarbons, sulphur, nitrogen, oxygen and some metals, such as ferrum and copper. Copper is the most reactive metal which catalyzes fuel oxidation. ${ }^{6,8}$ Deposits are further increased in the presence of mercaptans, thiols, sulfides, disulfides and organic acids. ${ }^{5,6,9}$

The study of OS has become exceptionally important due to an increasing demand for fuel quality and the need to store fuel for a longer period of time. A number of methods have been developed and proposed for determination of the diesel fuel OS. All of those aim at simulating conditions which occur during fuel storage. However, they are time consuming, demanding and require large amounts of samples. Therefore, there is a clear need for the development of a faster and more efficient method. Owing to its complex composition and the components which the fuel is in contact with, none of the existing methods encompasses all the possible conditions diesel fuel might be subjected to and all chemical reactions which can take place in fuels.

Hence, the aim of this paper is to explore the possibilities of nuclear magnetic resonance spectroscopy for OS determination of diesel fuels. NMR spectroscopy is one of the most powerful methods in identification and structural analysis of compounds and compound mixtures. The technique has also proven useful for the analysis 
of oil, oil derivatives and products. ${ }^{10-17}$ In complex mixtures such as mineral fuels, high resolution ${ }^{1} \mathrm{H}$ and ${ }^{13} \mathrm{C}$ NMR spectroscopy can provide wealth of information on average structural parameters and quantitative distribution of hydrogens and carbons., ${ }^{3,10,11,13-17,20}$ Thus, we would like to explore whether a correlation between the OS values and NMR parameters can be established and further exploited as an alternative to standard methods.

\section{Experimental}

\section{1. Materials}

All diesel fuel samples used in this study were of commercial grade obtained in two Croatian refineries in the boiling point range from $180{ }^{\circ} \mathrm{C}$ to $350{ }^{\circ} \mathrm{C}$ at the atmospheric pressure. Samples were treated using the procedures described in the standards HRN EN ISO $590^{1}$ and HRN EN ISO $3170^{18}$ which defined the requirements for diesel fuel quality. The first one lists the quality characteristics which individual diesel fuel should possess, such as cetan number, cetan index, density, etc. Each of these are described in a separate standard procedure. The purpose of the second standard is to standardize the conditions for obtaining a sample of liquid or semiliquid hydrocarbons from a tank, drum or pipeline by manual means. It includes the procedures for the determination of the hydrocarbon quality, water content and determination of the contaminants which are not considered to be a part of the transferred liquid.

\section{2. Aging Procedure}

OS of all samples has been obtained by the use of the standard method for the determination of the oxidation stability of middle-distillate fuels under accelerated oxidizing conditions, ISO $12205 .{ }^{19} \mathrm{~A}$ test portion of a filtered middle-distillate fuel was kept at $95{ }^{\circ} \mathrm{C}$ for $16 \mathrm{~h}$ while bubbling oxygen trough the sample. After aging, the sample was cooled to approximately room temperature before filtering to obtain a measurable quantity of filterable insolubles. The filtration was performed by using the standard procedure as describe in ISO 12205. Adherent insolubles were then removed from the oxidation cell and associated glassware with a trisolvent (TAM), a solution of equal volumes of acetone, toluene and methanol. The trisolvent was evaporated to obtain the adherent insolubles. The sum of the filterable and adherent insolubles is expressed as $\mathrm{g} / \mathrm{m}^{3}$ and must be less than $25 \mathrm{~g} / \mathrm{m}^{3}$.

\section{3. NMR Spectroscopy}

All the ${ }^{1} \mathrm{H}$ NMR spectra were recorded on a Bruker Avance $300 \mathrm{NMR}$ spectrometer operating at $300 \mathrm{MHz}$ for ${ }^{1} \mathrm{H}$ and $75 \mathrm{MHz}$ for ${ }^{13} \mathrm{C}$ using a $\mathrm{C} / \mathrm{H}$ dual $5 \mathrm{~mm}$ probe. The ${ }^{1} \mathrm{H}$ NMR experiments were carried out using $5 \%(\mathrm{w} / \mathrm{v})$ solution in $\mathrm{CDCl}_{3}(99.8 \%$ Aldrich) with 32 scans, $10 \mathrm{~s}$ recycle delay, $7.6 \mu \mathrm{s} \pi / 2$ pulse length and $16 \mathrm{~K}$ time domain data. Chemical shifts were reported relative to tetramethylsilane (TMS) used as an internal standard. The experiments were performed at room temperature. All measurements were repeated several times and results were expressed as mean values.

\section{4. Statistical Data Analysis}

Experimental data were statistically evaluated by using linear and multiple linear regression methods. The correlations between the oxidation stability determined by the standard method and integrated proton signal values were first obtained using the simple linear regression analysis. The functional groups which showed satisfying correlation were then used for setting up the model equation by using multiple linear regression method. The developed model equation was tested with a new set of samples.

\section{Results and Discussion}

As mentioned, NMR spectroscopy has a very distinctive position in the analysis of complex hydrocarbon compounds in middle-distillate fuels with respect to the types of functional groups. ${ }^{20-22}$ Here, 174 samples collected from the regular production refineries have been analyzed in an attempt to develop a method for determining OS of diesel fuel by ${ }^{1} \mathrm{H}$ NMR spectroscopy. As previously mentioned, the existing standard methods are complicated and time consuming. The samples used in this study were commercial diesel fuel blends obtained by different processes without additives. One set of 61 samples was used for setting up a statistical model (training set), and the other set of 113 samples was used to validate established correlations (validation set). The samples were collected during a period of 6 years, including a wide range of products derived from crude oil of different origin. It has already been demonstrated that ${ }^{1} \mathrm{H}$ NMR spectra of diesel fuel can be divided into seven spectral regions ${ }^{23}$ which are characteristic of specific structural group resonance signals. Owing to the complexity of diesel fuels, ${ }^{1} \mathrm{H}$ NMR spectra (Figure 1) consist of large number of overlapping signals belonging to different hydrocarbon types. Signal assignment in the ${ }^{1} \mathrm{H}$ NMR spectrum of diesel fuel samples was made according to previously established protocol developed in our laboratory. ${ }^{23}$ Table 1 lists the characteristic functional groups in diesel fuels, the spectral regions in which their protons resonate and letters designating integrated regions of interest. Integrated proton peak intensities are proportional to the number of hydrogen nuclei in each functional group. The numerical values of the integral allows for the direct determination of their percentage without prior calibration. 


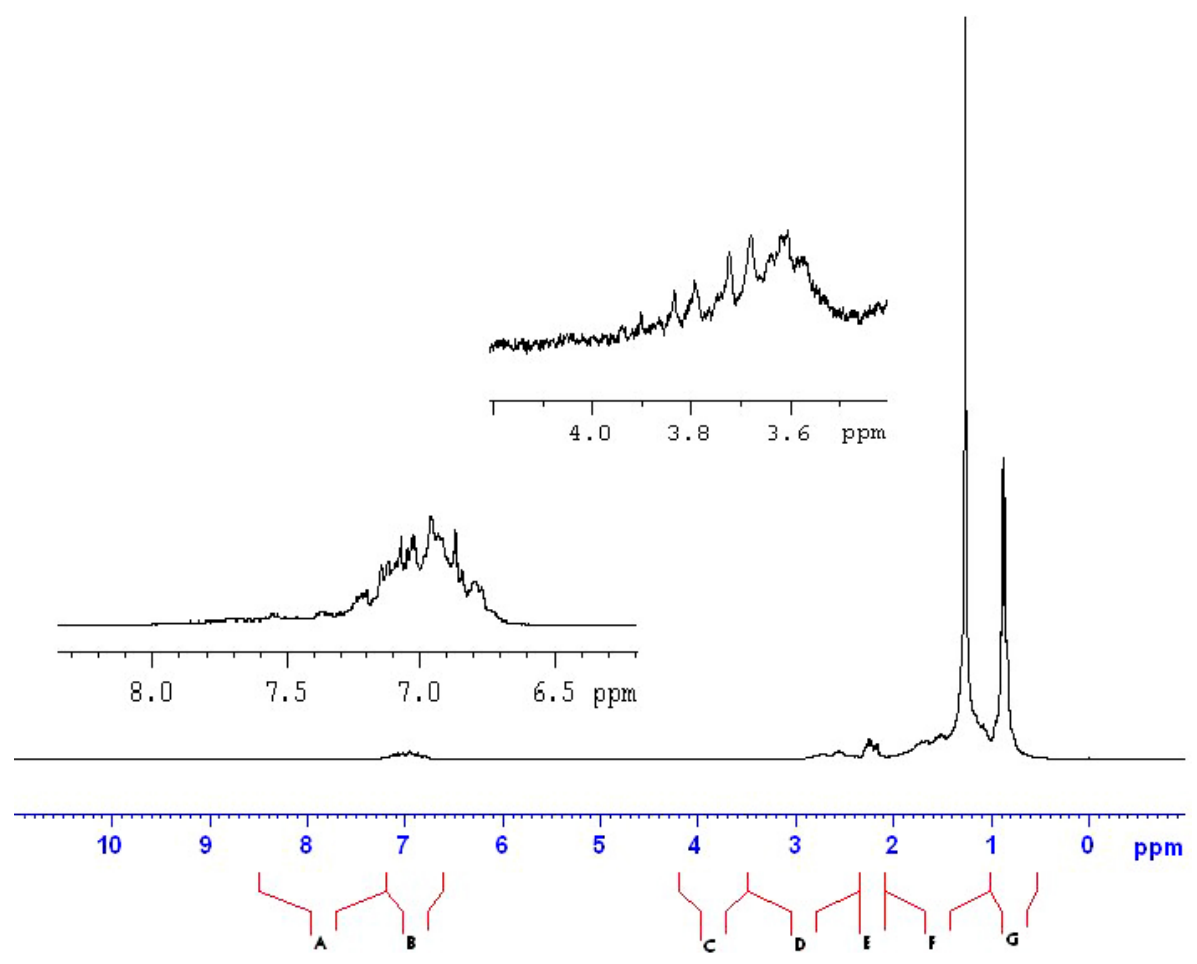

Figure 1. Typical ${ }^{1} \mathrm{H}$ NMR spectrum of a diesel fuel sample.

Table 1. Characteristic functional groups and ${ }^{1} \mathrm{H}$ NMR chemical shift ranges.

\begin{tabular}{|c|c|}
\hline Functional group ${ }^{23}$ & $\begin{array}{c}\text { Chemical shift } \\
\delta / p p m\end{array}$ \\
\hline Polyaromatic (A) & $7.20-9.00$ \\
\hline Monoaromatic (B) & $6.60-7.20$ \\
\hline Bridge $\mathrm{CH}_{2}(\mathrm{C})$ & $3.50-4.20$ \\
\hline $\mathrm{CH}_{2}$ and $\mathrm{CH}$ in $\alpha$ position to aromatic ring (D) & $2.34-3.50$ \\
\hline $\mathrm{CH}_{3}$ in $\alpha$ position to aromatic ring (E) & $2.08-2.34$ \\
\hline $\mathrm{CH}_{2}$ and $\mathrm{CH}$ in the paraffinic chain $(\mathrm{F})$ & $1.00-2.08$ \\
\hline $\mathrm{CH}_{3}(\mathrm{G})$ & $0.50-1.00$ \\
\hline
\end{tabular}

The proton integral values of functional groups of interest and oxidation stability determined by the standard method $\left(\mathrm{OS}_{\mathrm{EN} \mathrm{ISO}}\right)$ are given in the Supporting Information (Tables S1). In the first phase of statistical evaluation, $\mathrm{OS}_{\mathrm{EN} \mathrm{ISO}}$ data has been correlated with ${ }^{1} \mathrm{H}$ NMR peak intensities. A simple linear regression analysis has been performed first. Poor correlation has been determined for hydrogens in polyaromatic nuclei (A), those in the bridged aromatic rings (C), $\mathrm{CH}_{2}$ and $\mathrm{CH}$ groups in $\alpha$ position to aromatic ring (D) and protons in $\mathrm{CH}_{3}$ groups $(\mathrm{G})$. On the other hand, a satisfying correlation for this kind of complex mixtures has been found between $\mathrm{OS}_{\mathrm{EN} \text { Iso }}$ and the following functional groups in the ${ }^{1} \mathrm{H}$ NMR spectrum: hydrogens in monoaromatic nuclei (B), hydrogens in $\mathrm{CH}_{3}$ groups in $\alpha$ position to aromatic ring (E) and hydrogens in $\mathrm{CH}_{2}$ and $\mathrm{CH}$ groups in the paraffinic chains (F). The results are presented in Table 2.
Table 2. Correlation coefficients obtained for selected functional groups.

\begin{tabular}{lcc}
\hline Functional group & $\mathbf{r}^{\mathbf{2}}$ & $\mathbf{r}$ \\
\hline Monoaromatic (B) & 0.56 & 0.75 \\
$\mathrm{CH}_{3}$ in $\alpha$ position to aromatic ring (E) & 0.60 & 0.77 \\
$\mathrm{CH}_{2}$ and $\mathrm{CH}$ in the paraffinic chains (F) & 0.41 & 0.64 \\
\hline
\end{tabular}

Therefore, we used protons in groups B, E and F for further statistical analysis. Subsequently, we applied multiple linear regression analysis to establish correlation between $\mathrm{OS}_{\mathrm{EN} \text { ISO }}$ and proton peak integrals of selected functional groups in Table 2. The following equation (1) has been established and proposed:

$$
\mathrm{OS}_{\mathrm{NMR}}=2.21 \mathrm{~B}+5.16 \mathrm{E}-1.04 \mathrm{~F}+53.43
$$

The $r$ was found to be 0.80 and $\mathrm{r}^{2}$ was found to be 0.64 . This can be taken as a satisfactory degree of correlation for such a complex system consisting of thousands of different compounds.

In order to validate the proposed model a new set of 113 samples was then used (data presented in Table S2). The model equation was tested by comparing the $\mathrm{OS}_{\mathrm{EN} \text { ISO }}$ values and $\mathrm{OS}_{\mathrm{NMR}}$ values determined by ${ }^{1} \mathrm{H}$ NMR spectroscopy. The standard deviation was estimated to be $\sigma=$ 4.4 which is considered as highly acceptable for such classes of compound mixtures. ${ }^{19}$ Therefore, the main advantage of ${ }^{1} \mathrm{H}$ NMR spectroscopy with respect to the standard procedures is that the total analysis time per sample is 
considerably reduced to less than 15 minutes compared to more than 15 hours usually needed for standard methods. Furthermore, much lower quantity of a sample $(<0,1 \mathrm{ml})$ is needed for analysis. In addition, a time consuming sample preparation step is omitted.

\section{Conclusions}

In this paper a new approach for the determination of the diesel fuel oxidation stability by ${ }^{1} \mathrm{H}$ NMR spectroscopy and statistical analysis was proposed. For that purpose 174 commercial diesel fuel samples were evaluated. Multiple linear regression analysis was used to determine the correlation between the oxidation stability obtained by the standard method and NMR data. The results indicate that oxidation stability of a diesel fuel can be estimated from a single ${ }^{1} \mathrm{H}$ NMR spectrum in a short time. This approach can be very useful for quality control and an alternative to standard methods because it is efficient, fast and substantially simplifies determination of oxidation stability.

\section{Acknowledgements}

We thank the Ministry of Science, Education and Sports of the Republic of Croatia (Project No. 1191191342-1083) for the financial support.

\section{References}

1. HRN ISO 590:2009. Automotive fuels - Diesel - Requirements and test method. Croatian Standards Institute 2010, 1-7.

2. A. Adhvaryu, Y. K. Sharma, I. D. Singh, Fuel 1999, 78, 1293-302. http://dx.doi.org/10.1016/S0016-2361(99)00054-X

3. J. P. Vuković, S. Telen, V. Srića, P. Novak, Croat. Chem. Acta 2011, 84, 537-541. http://dx.doi.org/10.5562/cca1874

4. Z. Mužikova, F. Prochaska, M. Pospišil, Fuel 2010, 89, 3534-35399. http://dx.doi.org/10.1016/j.fuel.2010.06.019

5. J. F. Pedley, R. W. Hiley, R. A. Hancock, Fuel 1987, 66, 1646-51. http://dx.doi.org/10.1016/0016-2361(87)90356-5
6. A. Doyle, M. L. B Tristao, J. Felcman, Fuel 2006, 85, 2195201. http://dx.doi.org/10.1016/j.fuel.2006.03.030

7. G. Tian, D. Xia, F. Zhan, Energy Fuels 2004, 18, 49-53. http://dx.doi.org/10.1021/ef030066q

8. G. S. Pande, D. R. Hardy In: Proceedings of the 5th international conference on stability and handling of liquid fuels, Rotterdam, The Netherlands, 1994, pp.195-209.

9. J. H. Worstell, S. R. Daniel, G. Frauenhoff, Fuel 1981, 60, 485-487. http://dx.doi.org/10.1016/0016-2361(81)90109-5

10. Y. K. Sharma, A. Adhvaryu, J. M. Perez, S. Z. Erhan, Fuel Process.Technol. 2008, 89, 984-991. http://dx.doi.org/10.1016/j.fuproc.2008.04.001

11. G. S. Kapur, M. Findeisen, S. Berger, Fuel 2000, 79, 13475. http://dx.doi.org/10.1016/S0016-2361(99)00271-9

12. V. Bansal, G. J. Krishna, A. P. Singh, A. K. Gupta, A. S Sarpal, Energy Fuels 2008, 22, 410-415. http://dx.doi.org/10.1021/ef0701211

13. J. Burri, R. Crockett, R. Hany, D. Rentsch, Fuel 2004, 83, 187-193. http://dx.doi.org/10.1016/S0016-2361(03)00261-8

14. C. R. Kaiser, J. L. Borges, A. R .Santos, D. A. Azevedo, L. A. D. Avila, Fuel 2010, 89, 99-104. http://dx.doi.org/10.1016/j.fuel.2009.06.023

15. J. Mühl, V. Srića, Fuel 1987, 66, 1146-1149. http://dx.doi.org/10.1016/0016-2361(87)90314-0

16. J. Mühl, V. Srića, M. Jednačak, Fuel 1989, 68, 201-3. http://dx.doi.org/10.1016/0016-2361(89)90323-2

17. J. Mühl, V. Srića, M. Jednačak, Fuel 1993, 72, 987-989. http://dx.doi.org/10.1016/0016-2361(93)90297-F

18. HRN EN ISO 3170:2005. Petroleum liquids - Manual sampling. Croatian Standard Institute 1994, 1-55.

19. EN ISO 12205:1996. Petroleum products - Determination of the oxidation stability of middle-distillate fuels. Switzerland 1996, 1-7.

20. D. J. Cookson, B. E. Smith, Anal. Chem. 1985, 57, 864-71. http://dx.doi.org/10.1021/ac00281a020

21. D. J. Cookson, C. P. Lloyd, B. E. Smith, Energy Fuels 1988 , 2, 854-860. http://dx.doi.org/10.1021/ef00012a021

22. G. S. Kapur, A. Ecker, R. Meusinger, Energy Fuels 2001, 15, 943-948. http://dx.doi.org/10.1021/ef010021u

23. J. Mühl, V. Srića, B. Mimica, M. Tomašković, Anal. Chem. 1982, 54, 1871-1874. http://dx.doi.org/10.1021/ac00248a049

\section{Povzetek}

$\mathrm{Z}$ uporabo ${ }^{1} \mathrm{H}$ NMR spektroskopije in večfaktorske linearne regresijske analize smo določili oksidacijsko stabilnost dizelskega goriva. Oksidacijska stabilnost je ena od najpomembnejših lastnosti, ki vplivajo na lastnosti in kakovost dizelskega goriva. Pokazali smo, da so integrali intenzitet signalov, ki pripadajo določenim funkcionalnim skupinam v ${ }^{1} \mathrm{H}$ NMR spektrih v dobri korelaciji z oksidacijsko stabilnostjo. Ta pristop določanja oksidacijske stabilnosti je hiter, nedestruktiven in zahteva majhne količine vzorcev. Zaradi tega bi se lahko uporabljal kot alternativa za obstoječe standardne metode. 